\title{
Case Study Report: Tingkat Pengetahuan Dokumentasi Asuhan Keperawatan terhadap Pelaksanaan Dokumentasi Asuhan Keperawatan di RS PKU Muhammadiyah Yogyakarta
}

\author{
Aini Inayati ${ }^{1}$, Sriyati ${ }^{2}$ \\ ${ }^{1}$ Program Studi Ilmu Keperawatan, Universitas Alma Ata, Indonesia \\ ${ }^{2}$ Rumah Sakit PKU Muhammadiyah Yogyakarta, Indonesia \\ Email: ainiinayati@almaata.ac.id
}

\begin{abstract}
Abstrak
Dokumentasi keperawatan sangat penting bagi tenaga keperawatan dalam memberikan asuhan keperawatan karena pelayanan keperawatan yang diberikan kepada klien membutuhkan pencatatan dan pelaporan yang dapat digunakan sebagai tanggung jawab dan tanggung gugat dari berbagai kemungkinan masalah yang di alami klien. Desain penelitian yang digunakan adalah analitik dengan pendekatan cross sectional, sampel dalam penelitian ini berjumlah 113 reponden. Analisa data menggunakan Cross table. Hasil dari 113 responden didapatkan tingkat pengetahuan perawat tentang dokumentasi keperawatan baik sebanyak 42 responden (37,3\%), Cukup sebanyak 41 (36,2\%), dan kurang sebnayak 30 (26,5). Sedangkan hasil analisa berdasarkan pelaksanaan dokumentasi asuhan keperawatan lengkap sebanyak 60 responden (53,0\%), dan tidak lengkap 53 (47\%). Analisa cross tab didapatkan pengetahuan tentang dokumentasi keperawatan baik dengan pelaksanaan dokumentasi asuhan keperawatan lengkap sebanyak $20(17,6 \%)$ responden, lebih baik daripada tingkat pengatahuan tentang dokumentasi keperawatan kurang dengan pelaksanaan dokumentasi asuhan keperawatan tidak lengkap sebanyak $12(10,6 \%)$ responden. Kesimpulannya pelaksanaan dokumentasi asuhan keperawatan sebagian besar dalam kategori lengkap dan ada hubungan antara tingkat penegtahuan perawat pada pelaksanaan pendokumentasian asuhan keperawatan secara lengkap dan akurat, sehingga dapat meningkatkan kualitas asuhan dan kontinuitas pelaynan keperawatan.
\end{abstract}

Kata Kunci: Dokumentasi Asuhan Keperawatan; Pengetahuan

\section{Report of Case Study: Level of Knowledge Documentation of Nursing Care on Implementation of Nursing Documentation in PKU Muhammadiyah Hospital}

\begin{abstract}
Abstrack
Nursing documentation is very important for nursing staff in providing nursing care for nursing services provided to clients who need recording and reporting that can be used as accountability and accountability responsibility for various problems that arise in experienced clients. The research design used was analytical using cross sectional, the sample in this study was obtained 113 respondents. Data analysis using Cross table. The results of 113 respondents obtained knowledge of nurses on good nursing documentation as many as 42 respondents (37.3\%), Enough as many as 41 (36.2\%), and less than 30 (26.5). While the results of the analysis at the time of the implementation of complete nursing care were 60 respondents (53.0\%), and incomplete 53 (47\%). Cross tab analysis obtained knowledge about good nursing documentation with the implementation of complete nursing care documentation as many as 20 (17.6\%) respondents, better than the level of knowledge about nursing documentation less with the implementation of incomplete nursing care documentation $12(10.6 \%)$ respondents. This study concludes that the implementation of the nursing care convention is mostly in full categories. And there is a relationship between the level of knowledge of nurses in the implementation of complete and accurate nursing care documentation, that it can improve the quality of care and continuity of nursing care.
\end{abstract}

Keywords: Documentation of Nursing Care; Knowledge

Received:01/01/2020: Published:01/05/2020

Indonesian Journal of Hospital Administration Vol. 3 No.1 


\section{PENDAHULUAN}

Rendahnya pendokumentasian asuhan keperawatan di pengaruhi oleh beberapa factor, antara lain: tingkat pendidikan, pengetahuan, motivasi, format asuhan keperawatan dan pengalaman kerja perawat itu sendiri (1). Dalam UU RI No 23 Tahun 1992 tentang kesehatan dalam, pasal 53 ayat 2 sebagai berikut "Tenaga kesehatan dalam melaksanakan tugasnya berkewajiban untuk mematuhi standar profesi dan menghormati hak-hak pasien”. Dokumentasi asuhan keperawatan banyak di kritik dengan berbagai alasan antara lain: perawat mengatakan bahwa pendokumentasian hanya membuang waktu karena tidak ada yang membaca catatan tersebut. Sementara dokumentasi proses keperawatan masih belum dilakukan secara optimal oleh perawat dalam melaksanakan tugasnya membuat asuhan keperawatan. Dokumentasi keperawtan sendiri mempunyai makna yang penting di lihat dari berbagai aspek: hukum, pendidikan, jaminan mutu, komunikasi, keuangan, penelitian dan akreditasi (3).

Berdasarkan penjelasan Ali (4), Dokumentasi keperawatan merupakan dokumentasi yang legal bagi profesi keperawatan. Oleh karena itu, dokumentasi keperawatan harus memenuhi standar yang telah ditentukan. Komisi Gabungan Akreditasi Organisasi Pelayanan Kesehatan JCAHO, 2015 merekomendasikan standar dokumentasi keperawatan yang meliputi: 1) Pengkajian awal dan pengkajian ulang. 2) Diagnosis keperawatan dan kebutuhan asuhan keperawatan klien. 3) Rencana tindakan asuhan keperawatan. 4) Tindakan asuhan keperawatan yang diberikan atas respon klien. 5) Hasil dari asuhan keperawatan dan kemampuan untuk tindak lanjut asuhan keperawatan setelah klien dipulangkan.

Dokumentasi merupakan komunikasi secara tertulis sehingga perawat dituntut untuk dapat mendokumentasikan secara benar (5). Perawat memerlukan standar dokumentasi sebagai petunjuk dan arah dalam pemeliharaan pencatatan/dokumentasi kegiatan serta petunjuk dalam membuat pola/format pencatatan yang tepat. Dokumentasi yang baik harus mengikuti karakteristik standar keperawatan (4). Standar dokumentasi adalah suatu pernyataan tentang kualitas dan kuantitas dokumentasi yang dipertimbangkan secara adekuat dalam suatu situasi tertentu. Dengan adanya standar bahwa adanya suatu ukuran terhadap kualitas dokumentasi keperawatan (6).

Hasil penelitian terdahulu di RSUD kota Yogyakarta di peroleh kualitas dokumentasi di Paviliun Vinolia dan Ruang Dahlia RSUD kota Yogyakarta sudah baik dengan prosentase rata - rata askep pengkajian adalah $87,5 \%$, diagnosa $79,47 \%$, perencanaan $64,72 \%$, tindakan 87,64\%, evaluasi 79, 73\%, dan dari aspek catatan asuhan keperawatan sebesar $79,07 \%$. Dan rata - rata secara umum kualitas dokumentasinya adalah $79,70 \%$. Kemudian hasil evaluasi terhadap dokumentasi proses asuhan keperawatan besar ditemukan kurang 
dari 40\% yang memenuhi kriteria (7). Berdasarkan hasil survei awal sebanyak 15 Perawat di RS PKU Muhammadiyah Yogyakara di dapatkan hasil tingkat pengetahuan baik sebanyak 5 orang $(45,2 \%)$, tingkat pengetahuan cukup sebanyak 4 orang (29\%), dan tingkat pengetahuan kurang sebanyak 6 orang $(50,85 \%)$. Hasil penelitian di RSUD Wates juga menunjukkan masih terdapat dokumentasi keperawatan $77,5 \%$ dalam assesment pengkajian dokumentasi yang dilakukan perawat (8). Didukung juga oleh penelitian yang menunjukkan hasil perawat dengan beban kerja tinggi dalam mengisi dokumentasi asuhan keperawatan kurang lengkap sejumlah 20 perawat (30,77\%) (9).

Dengan demikian bisa dalam pelaksanaan dokumentasi keperawatan yang bersifat objektif, akurat dan menggambarkan keadaan klien serta apa yang terjadi pada diri klien, sehingga apabila diperlukan dokumentasi ini dapat menunjukkan bahwa perawat telah mencatat dengan benar dan tidak bertentangan dengan kebijakan atau peraturan institusi pemberi pelayanan kesehatan. Berdasarkan kesenjangan diatas maka peneliti tertarik melihat fenomena bagaimana tingkat pengetahuan perawat dalam pelaksanaan dokumentasi asuhan keperawatan.

\section{BAHAN DAN METODE}

Desain penelitian yang digunakan analitik dengan pendekatan cross sectional yaitu memberikan gambaran tentang pengaruh tingkat pengetahuan dengan pelaksanaan dokumentasi asuhan keperawatan dimana pengumpulan data variabel independen dan dependen dan di laksanakan dalam waktu bersamaan dalam satu menekan pada waktu pengukuran atau observasi data.Jumlah sampel pada penelitian ini sebanyak 113 responden atau perawat.

Pada penelitian ini sampel diambil dari yang memenuhi kriteria inklusi berjumlah 113 responden. Kriteria inklusi pada penelitian ini adalah: Bersedia menjadi responden, Pendidikan minimal DIII Keperawatan, Perawat yang tidak sedang dalam masa cuti. Perawat pelaksana, bertugas di ruangan perawatan. Kriteria eklusi: Perawat yang sedang cuti, pendidikan SPK, perawat yang sedang tugas belajar dan Perawat yang sedang menjabat struktural.

\section{HASIL DAN PEMBAHASAN}

Tabel 1 Distribusi tingkat pengetahuan tentang dokumentasi keperawatan

\begin{tabular}{lll}
\hline Tingkat pengetahuan & Jumlah & Prosentase \\
\hline Baik & 42 & $37,3 \%$ \\
Cukup & 41 & $36,2 \%$ \\
Kurang & 30 & $26,5 \%$ \\
\hline Jumlah & 113 & $100 \%$ \\
\hline
\end{tabular}


Berdasarkan Tabel 1 dari 113 responden didapatkan kurang dari sebagian responden tingkat pengetahuan tentang dokumentasi keperawatan baik sebanyak 42 responden $(37,3 \%)$. Sehingga dapat disimpulkan bahwa tingkat pengetahuan tergolong baik sehingga signifian dan berdampak positif pada kegiatan asuhan keperawatan.

Tabel 2 Distribusi pelaksanaan dokumentasi asuhan keperawatan

\begin{tabular}{lcl}
\hline Dokumentasi asuhan keperawatan & Jumlah & Prosentase \\
\hline Lengkap & 60 & $53,0 \%$ \\
Tidak lengkap & 53 & $47,0 \%$ \\
\hline Jumlah & 113 & $100 \%$ \\
\hline
\end{tabular}

Berdasarkan Tabel 2 dari 113 responden didapatkan lebih dari sebagian responden pelaksanaan dokumentasi asuhan keperawatan lengkap sebanyak 60 responden $(53,0 \%)$, sedangan tidak lengkap sebanyak 53 reponden (47,0\%).

Tabel 3 Tingkat pengetahuan dengan pelaksanaan dokumentasi asuhan keperawatan

\begin{tabular}{lllllll}
\hline \multirow{3}{*}{ Tingkat pengetahuan } & \multicolumn{4}{c}{ Jumlah } & \multirow{2}{*}{ Jumlah } \\
\cline { 2 - 6 } & \multicolumn{3}{c}{ Lengkap } & \multicolumn{2}{c}{$\begin{array}{c}\text { Tidak } \\
\text { Lengkap }\end{array}$} & \\
\cline { 2 - 6 } & $\mathbf{n}$ & $\%$ & $\mathbf{n}$ & $\%$ & $\mathbf{n}$ & $\%$ \\
\hline Baik & 0 & 7,6 & 2 & 9,4 & 2 & 7,28 \\
Cukup & 3 & 0,3 & 9 & 6,8 & 2 & 7,2 \\
Kurang & 7 & 5,0 & 2 & 0,6 & 9 & 5,6 \\
\hline
\end{tabular}

Hasil penelitian pada Tabel 3 menunjukkan bahwa tingkat pengetahuan perawat tentang dokumentasi keperawatan baik dengan pelaksanaan dokumentasi asuhan keperawatan lengkap sebanyak 20 (17,6\%) responden, lebih baik daripada tingkat pengetahuan perawat tentang dokumentasi keperawatan kurang dengan pelaksanaan dokumentasi asuhan keperawatan tidak lengkap sebanyak 12 (10,6\%) responden. Dari hasil di atas berarti menunjukkan ada hubungan tingkat pengetahuan perawat tentang dokumentasi keperawatan dengan pelaksanaan dokumentasi asuhan keperawatan.

Pengetahuan adalah merupakan hasil dari tahu dan ini terjadi setelah orang melakukan penginderaan terhadap suatu objek tertentu. Sebagian besar pengetahuan manusia diperoleh melalui mata dan relingga (10). Dokumentasi keperawatan merupakan pengumpulan, penyimpanan guna mempertahankan sejumlah kejadian (11). Sedangkan tujuan utama dari pendokumentasian adalah untuk: 1) Mengidentifikasi status kesehatan klien dalam rangka mencatat kebutuhan klien, merencanakan, melaksanakan tindakan keperawatan dan mengevaluasi tindakan dan 2) Dokumentasi untuk penelitian, keuangan, hukum dan etika. Hal ini juga menyediakan bukti legal dokumentasi sebagai pertanggungjawaban kepada klien, informasi terhadap perlindungan individu, bukti aplikasi standart praktik keperawatan, sumber informasi statistik untuk standart dan riset keperawatan, pengurangan biaya informasi, sumber informasi untuk data yang harus dimasukan, komunikasi konsep resiko tindakan keperawatan, informasi untuk murid, 
persepsi hak klien, dokumentasi untuk tenaga profesional dan tanggungjawab etik dan mempertahankan kerahasiaan informasi klien, suatu data keuangan yang sesuai, data perencanaan pelayanan kesehatan dimasa akan datang (12).

Semakin tinggi tingkat pengetahuan perawat tentang dokumentasi keperawata, semakin tinggi pemahaman dalam pelaksanaan dokumentasi perawatan agar dalam melakukan pencatatan keperawatan yang berguna untuk kepentingan klien dalam memberikan pelayanan kesehatan dengan dasar komunikasi yang akurat dan lengkap secara tertulis. Pendapat di atas sesuai dengan hasil penelitian ini karena sebanyak 113 perawatdidapatkan tingkat pengetahuan perawat tentang dokumentasi keperawatan baik dengan pelaksanaan dokumentasi asuhan keperawatan lengkap sebanyak 20 (17,6\%) responden. Hal tersebut membuktikan ada hubungan tingkat pengetahuan perawat tentang dokumentasi keperawatan dengan pelaksanaan dokumentasi asuhan keperawatan.

\section{SIMPULAN DAN SARAN}

Tingkat pengetahuan perawat tentang dokumentasi keperawatan lebih dari sebagian dalam kategori baik. Pelaksanaan dokumentasi asuhan keperawatan sebagian besar dalam kategori lengkap. Terdapat hubungan tingkat pengetahuan tentang dokumentasi keperawatan dengan kelengkapan dokumentasi asuhan keperawatan.

\section{DAFTAR PUSTAKA}

1. Patricia A. Potter \& Perry, Anne G. Buku Ajar Fundamental Keperawatan (konsep, proses, dan praktik). Jakarta: EGC. 2011.

2. Indonesia, D. K. R. Undang-Undang Republik Indonesia Nomor 36 Tahun 2009 Tentang Kesehatan. 2013.

3. Nursalam. Konsep dan penerapan metodologi penelitian keperawatan. Jakarta. 2008.

4. Ali, Z. Pengantar Keperawatan Keluarga. Jakarta: EGC. 2009.

5. Handayaningsih, Isti. Dokumentasi Keperawatan "DAR" panduan, konsep dan aplikasi. Jogjakarta: MITRA CENDIA Press. 2007.

6. Martini. Hubungan Karakteristik Perawat, Sikap, Beban Kerja, Supervisi dengan Pendokumentasian Asuhan Keperawatan di Rawat Inap BPRSUD Salatiga. Thesis FKM-UNDIP. 2007.

7. Pramujiwati, D., Keliat, B. A., \& Wardani, I. Y. Pemberdayaan Keluarga Dan Kader Kesehatan Jiwa Dalam Penanganan Pasien Harga Diri Rendah Kronik Dengan Pendekatan Model Precede L. Green Di Rw 06, 07 Dan 10 Tanah Baru Bogor Utara. Jurnal Keperawatan Jiwa, 1(2). 2013.

8. Kurniawandari, E., \& Fatimah, F. S. Implementation of Documentation of Nursing Care in Wates Hospital. Jurnal Ners dan Kebidanan Indonesia, 6(2), 68-75. 2019.

9. Kimalaha, N., Mahfud, M., \& Anggraini, A. N. Pengetahuan dan Beban Kerja Perawat Berhubungan Dengan Kelengkapan Pendokumentasian Asuhan Keperawatan di 
Bangsal Penyakit Dalam dan Bedah. Indonesian Journal of Hospital Administration, 1(2), 79-88. 2019.

10. Notoatmodjo, Soekidjo. Pendidikan Dan Perilaku Kesehatan. Rineka Cipta. Jakarta. Pendidikan Dan Perilaku Kesehatan. Rineka Cipta. Jakarta. 2003.

11. Fishback, L. J. Pathology, Philadelphia: Elsevier Mosby, p 217 - 220. 2002.

12. Nursalam. Pendekatan praktis metodologi Riset Keperawatan. Jakarta. Info Medika. 2001. 